\title{
TINJAUAN KEBUTUHAN SUMBER DAYA MANUSIA DI REKAM MEDIS BERDASARKAN METODE ANALISIS BEBAN KERJA KESEHATAN (ABK-KeS) DI RUMAH SAKIT UMUM DARMAYU PONOROGO
}

\author{
Mey Chrismawanti \\ Prodi D-III Rekam Medis dan Informasi Kesehatan Sekolah Tinggi Ilmu Kesehatan Buana \\ Husada Ponorogo \\ meychrismawanti@gmail.com
}

\begin{abstract}
The ABK Kes method is a method of calculating HRH needs based on the workload carried out by each type of HRH in accordance with the main tasks and functions, which have 6 calculation steps. The purpose of this study was to determine the needs of human resources in the Medical Record based on the Health Workload Analysis Method (ABK Kes). This type of research uses descriptive research by observation and interviews. The population of this study amounted to 5 officers consisting of medical record officers. The sampling technique uses total sampling. Data were analyzed descriptively. The results of HR calculation using the ABK Kes method at the "Darmayu" Hospital in Ponorogo need to add officers in the registration section to 1 officer, assembling 2 officers and coding 2 officers. Suggestions from researchers are the addition of human resources medical records in the registration, assembling, and coding to improve the quality of performance of officers at the "Darmayu" Ponorogo General Hospital.
\end{abstract}

Keywords:Human Resource Needs, ABK Kes Method

\section{PENDAHULUAN}

$\begin{array}{lcr}\text { Rumah } & \text { Sakit adalah } & \text { institusi } \\ \text { pelayanan kesehatan } & \text { yang } \\ \text { menyelenggarakan } & \text { pelayanan }\end{array}$ kesehatan perorangan secara paripurna yang menyediakan pelayanan rawat inap, rawat jalan, dan gawat darurat, (Undang-Undang RI Nomor 44 tahun 2009 pasal 1). Fungsi rumah sakit yaitu menyelenggarakan pelayanan pengobatan dan pemulihan kesehatan sesuai dengan standar pelayanan rumah sakit, meningkatkan kesehatan perorangan melalui pelayanan kesehatan yang paripurna tingkat kedua dan ketiga sesuai kebutuhan medis dan menyelenggarakan pendidikan dan pelatihan sumber daya manusia untuk meningkatkan kemampuan dalam pelayanan kesehatan. Untuk menjaga dan meningkatkan mutu rumah sakit harus mempunyai ukuran yang menjamin peningkatan mutu di semua tingkatan (Rustiyanto, 2010). Dalam menjalankan upaya kesehatan rumah sakit memerlukan upaya penunjang yaitu salah satunya unit rekam medis.

Rekam Medis adalah berkas yang berisi catatan dan dokumen antara lain identitas pasien, hasil pemeriksaan, pengolahan yang telah diberikan, serta tindakan dan pelayanan lain yang telah diberikan kepada pasien (Permenkes No: 269/MENKES/PER/III/2008). Pembuatan rekam medis bertujuan untuk mendapatkan data dari pasien mengenai riwayat kesehatan, riwayat penyakit dimasa lalu dan sekarang, selain itu upaya pengobatan yang diberikan kepada pasien sebagai meningkatkan pelayanan kesehatan, menjaga kerahasiaan dokumen rekam medis pasien dan alat bukti hukum.

Perencanaan Sumber Daya Manusia (SDM) merupakan salah satu tugas yang harus dilakukan Unit Menejemen Sumber Daya Manusia (MSDM) di Rumah Sakit Umum "Darmayu" Ponorogo. Perencanaan 
SDM yang dilakukan bertujuan untuk mengetahui kebutuhan SDM tiap unit dan proses rekrutmen karyawan di periode yang akan datang. Berkembangnya kualitas kinerja petugas dalam melayani dan menangani pasien dapat meningkatkan kepercayaan pada kualitas rumah sakit tersebut, maka dalam melayani pasien yang lebih cepat butuh tenaga rekam medis yang memadahi, selain itu dalam pendataan pasien dan hasil pelaporan dapat ditangani dengan cepat dan tepat.

Perencanaan kebutuhan SDM kesehatan berdasarkan metode analisis beban kerja kesehatan (ABK Kes) adalah suatu metode perhitungan kebutuhan sumber daya manusia kesehatan berdasarkan beban kerja yang dilaksanakan oleh setiap jenis SDMK pada tiap fasilitas pelayanan kesehatan (Fasyankes) sesuai dengan tugas pokok dan fungsinya. Metode ini dugunakan untuk menghitung kebutuhan semua jenis sumber daya manusia kesehatan (SDMK). Sebelum ada metode baru analisis beban kerja kesehatan (ABK Kes) dari depkes ada metode lain yaitu dengan metode Workload Indicators Of Staffing Need (WISN).

Berdasarkan studi pendahuluan yang dilakukan penelitian tanggal 17 Desember 2018 di Unit Rekam Medis Rumah Sakit Umum "Darmayu" Ponorogo, melalui wawancara petugas rekam medis bahwa membutuhkan tenaga rekam medis tambahan. Pedoman yang digunakan untuk menghitung analisis beban kerja yaitu metode perhitungan WISN. Data yang didapat untuk petugas filling memerlukan 2 petugas, coding 1 petugas, dan untuk bagian indexsing membutuhkan 2 petugas, kapasitas pasien setiap tahun meningkat membuat pengelolaan dokumen makin lambat dan mengelola data pasien tidak efisien.
Masalah dan data yang telah disampaikan maka dampak yang dapat ditimbulkan mengenai masalah tersebut adalah mempengaruhi kualitas kinerja rumah sakit tersebut dan dapat memperlambat pelayanan kepada pasien. Dengan cara menambah sumber daya manusia di rekam medis dapat mempercepat pelayanan kepada pasien, dan pasien merasa lebih puas dalam pelayanan di Rumah Sakit Umum "Darmayu" Ponorogo.

Kebutuhan sumber daya manusia di bagian rekam medis dapat dilakukan dengan cara menggunakan perhitungan kembali dengan metode baru yaitu Analisis Beban Kerja Kesehatan (ABK Kes) dari Depkes agar lebih akurat dalam perhitugan beban kerja petugas selanjutnya. Pelayanan dan pengelolaan data dokumen rekam medis lebih akurasi membuat pasien puas dalam pelayanan di Rumah Sakit Umum "Darmayu" Ponorogo. Analisis Beban Kerja Kesehatan yaitu suatu metode perhitungan kebutuhan SDMK berdasarkan pada beban kerja yang dilakukan oleh setiap jenis SDMK pada tiap fasilitas pelayanan kesehatan (Fasyankes) sesuai dengan tugas pokok dan fungsinya. Metode ini digunakan untuk menghitung kebutuhan semua jenis Sumber Daya Manusia Kesehatan.

\section{METODE PENELITIAN}

Penelitian ini menggunakan analisis deskriptif. Lokasi penelitian adalah RSU "Darmayu" Ponorogo. Sampel penelitian adalah 5 orang petugas petugas pendaftaran, assembling, coding, indeksing dan filling. Metode pengambilan data yang digunakan dalam penelitian ini dengan cara observasi, wawancara, dokumentasi dan dengan meminta data di bagian rekam medis. 


\section{HASIL PENELITIAN}

Perhitungan sumber daya manusia rekam medis di RSU "Darmayu" Ponorogo dengan metode ABK-Kes dapat dihitung sebagai berikut:

\section{A. Unit Tempat Pendaftaran Rawat Jalan (TPPRJ)}

1. Langkah 1 Menetapkan Fasyankes dan Jenis SDMK

Fasilitas Pelayanan Kesehatan :

Rumah Sakit

Unit : Tempat Pendaftaran

Rawat Jalan (TPPRJ)

2. Tabel 1.

Langkah 2 Menetapkan Waktu Kerja Tersedia/WKT

\begin{tabular}{|c|c|c|c|}
\hline Kode & $\begin{array}{l}\text { Kompone } \\
n\end{array}$ & Jumlah & Satuan \\
\hline $\mathbf{A}$ & Hari Kerja & $\begin{array}{l}52 \text { minggu } \\
x \quad 6 \text { hari= } \\
312\end{array}$ & $\begin{array}{l}\text { Hari/ } \\
\text { Tahun }\end{array}$ \\
\hline B & $\begin{array}{l}\text { Cuti } \\
\text { Pegawai }\end{array}$ & 6 & $\begin{array}{l}\text { Hari/ } \\
\text { Tahun }\end{array}$ \\
\hline C & $\begin{array}{l}\text { Libur } \\
\text { Nasional }\end{array}$ & 19 & $\begin{array}{l}\text { Hari/ } \\
\text { Tahun }\end{array}$ \\
\hline D & $\begin{array}{l}\text { Mengikuti } \\
\text { Pelatihan }\end{array}$ & - & $\begin{array}{l}\text { Hari/ } \\
\text { Tahun }\end{array}$ \\
\hline $\mathbf{E}$ & $\begin{array}{l}\text { Absen } \\
\text { (Sakit,dll) }\end{array}$ & 12 & $\begin{array}{l}\text { Hari/ } \\
\text { Tahun }\end{array}$ \\
\hline $\mathbf{F}$ & $\begin{array}{l}\text { Waktu } \\
\text { Kerja } \\
\text { (dalam } 1 \\
\text { minggu }\end{array}$ & 37,5 & $\begin{array}{l}\text { Jam/ } \\
\text { Mingg } \\
\text { u }\end{array}$ \\
\hline G & $\begin{array}{l}\text { Jam Kerja } \\
\text { Efektif } \\
(\mathrm{JKE})\end{array}$ & $\begin{array}{l}75 \% \mathrm{x} \\
37,5 \mathrm{jam}= \\
28.125\end{array}$ & $\begin{array}{l}\text { Jam/ } \\
\text { Mingg } \\
\mathrm{u}\end{array}$ \\
\hline H & $\begin{array}{l}\text { Waktu } \\
\text { Kerja } \\
\text { (dalam } \\
\text { hari) }\end{array}$ & $\begin{array}{l}28.125: 6 \\
=4.688\end{array}$ & $\begin{array}{l}\text { Jam/ } \\
\text { Hari }\end{array}$ \\
\hline I & $\begin{array}{l}\text { Waktu } \\
\text { Kerja } \\
\text { Tersedia } \\
\text { (hari) }\end{array}$ & $\begin{array}{l}312- \\
(6+19+12) \\
= \\
312- \\
37=275\end{array}$ & $\begin{array}{l}\text { Hari/ } \\
\text { Tahun }\end{array}$ \\
\hline $\mathbf{J}$ & $\begin{array}{l}\text { Waktu } \\
\text { Kerja } \\
\text { Tersedia } \\
\text { (jam) }\end{array}$ & $\begin{array}{l}312- \\
(6+19+12) \\
x 4.688 \\
=(312- \\
37) \times 4,688 \\
=275 \times 4,68 \\
8 \\
=1.289,2\end{array}$ & $\begin{array}{l}\text { Jam/ } \\
\text { Tahun }\end{array}$ \\
\hline
\end{tabular}

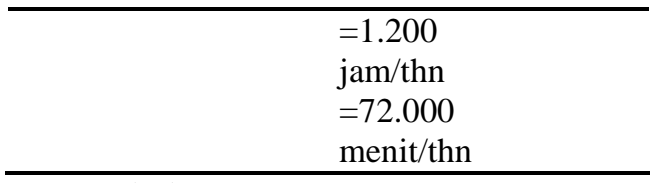

3. Tabel 2.

Langkah 3 Menetapkan Komponen Beban Kerja dan Norma Waktu

\begin{tabular}{lll}
\hline \multicolumn{2}{l}{ Uraian Tugas } & $\begin{array}{l}\text { Norma } \\
\text { Waktu }\end{array}$ \\
\hline 1. & Mendaftar pasien Rawat & 3 menit \\
Jalan & 10 menit \\
2. & Membuatkan register & 10 detik \\
3. & Membuat Kartu KIB & 10 detik \\
4. & Membuat tracer & 13,20 \\
\hline & Total & menit \\
\hline 4. & Langkah 4 Menghitung Standar \\
Beban Kerja (SBK) & \\
Standar Beban Kerja (SBK) $=$ \\
Waktu Kerja Tersedia \\
\hline Norma Waktu/Kegiatan Pokok \\
Standar Beban Kerja (SBK) $=$ \\
$\frac{72.000}{13,20 \quad=5.454}$
\end{tabular}

5. Langkah 5 Menghitung Standar Tugas Penunjang (STP) dan Faktor

Tugas Penunjang (FTP)

Faktor Tugas $\quad=$ (Waktu Kegiatan $)$ :

Penunjang (WKT) $x 100$

(FTP)

Standar Tugas $=(1 /(1-\mathrm{FTP} / 100))$

Penunjang(STP)

$$
\begin{aligned}
& \text { FTP }=13,20: 72.000 \times 100 \% \\
& =0,1 \% \\
& \begin{aligned}
\text { STP } & =(1 /(1-0,1 \% / 100)) \\
& =1
\end{aligned}
\end{aligned}
$$

\begin{tabular}{|c|c|}
\hline & Capaian (1 th) \\
\hline Kebutuhan & 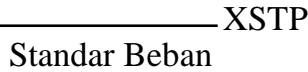 \\
\hline
\end{tabular}

6. Langkah 6 Menghitung Kebutuhan SDMK

(Tim Pusrengun SDM Kesehatan Badan PPSDM Kesehatan RI, 2015)

\begin{tabular}{ll}
\hline Bagian & Capaian $(1$ th $)$ \\
\hline Jumlah & 19.978 pasien/tahun \\
Pasien & \\
\hline
\end{tabular}


Kebutuhan Sumber Daya Manusia Kesehatan di bagian pendaftaran rawat jalan :

$$
\begin{aligned}
\text { SBK } & =5.454 \\
\text { STP } & =1 \\
\text { SDMK } & =19.978 / 5.454 \times 1 \\
& =4 \text { orang petugas pendaftaran }
\end{aligned}
$$

B. Unit Tempat Pendaftaran Rawat Inap dan Unit Gawat Darurat

1. Langkah 1 Menetapkan Fasyankes dan Jenis SDMK

Fasilitas Pelayanan Kesehatan : Rumah Sakit

Unit : Tempat Pendaftaran Rawat Inap dan Unit Gawat Darurat

\begin{tabular}{|c|c|c|c|}
\hline Kode & Komponen & Jumlah & Satuan \\
\hline $\mathbf{A}$ & Hari Kerja & $\begin{array}{l}52 \text { minggu } x \\
6 \text { hari }=312\end{array}$ & $\begin{array}{l}\text { Hari/ } \\
\text { Tahun }\end{array}$ \\
\hline B & $\begin{array}{l}\text { Cuti } \\
\text { Pegawai }\end{array}$ & 6 & $\begin{array}{l}\text { Hari/ } \\
\text { Tahun }\end{array}$ \\
\hline C & $\begin{array}{l}\text { Libur } \\
\text { Nasional }\end{array}$ & 19 & $\begin{array}{l}\text { Hari/ } \\
\text { Tahun }\end{array}$ \\
\hline D & $\begin{array}{l}\text { Mengikuti } \\
\text { Pelatihan }\end{array}$ & - & $\begin{array}{l}\text { Hari/ } \\
\text { Tahun }\end{array}$ \\
\hline $\mathbf{E}$ & $\begin{array}{l}\text { Absen } \\
\text { (Sakit,dll) }\end{array}$ & 12 & $\begin{array}{l}\text { Hari/ } \\
\text { Tahun }\end{array}$ \\
\hline $\mathbf{F}$ & $\begin{array}{lr}\text { Waktu } & \text { Kerja } \\
\text { (dalam } & 1 \\
\text { minggu } & \end{array}$ & 37,5 & $\begin{array}{l}\text { Jam/ } \\
\text { Minggu }\end{array}$ \\
\hline $\mathbf{G}$ & $\begin{array}{l}\text { Jam Kerja } \\
\text { Efektif } \\
(\mathrm{JKE})\end{array}$ & $\begin{array}{ll}75 \% & \mathrm{x} \\
37,5 \mathrm{jam} & = \\
28.125 & \end{array}$ & $\begin{array}{l}\text { Jam/ } \\
\text { Minggu }\end{array}$ \\
\hline $\mathbf{H}$ & $\begin{array}{lr}\text { Waktu } & \text { Kerja } \\
\text { (dalam } & 1 \\
\text { hari) } & \end{array}$ & $\begin{array}{l}28.125: 6= \\
4.688\end{array}$ & Jam/ Hari \\
\hline I & $\begin{array}{l}\text { Waktu Kerja } \\
\text { Tersedia } \\
\text { (hari) }\end{array}$ & $\begin{array}{l}312- \\
(6+19+12)= \\
312-37=275\end{array}$ & $\begin{array}{l}\text { Hari/ } \\
\text { Tahun }\end{array}$ \\
\hline $\mathbf{J}$ & $\begin{array}{l}\text { Waktu Kerja } \\
\text { Tersedia } \\
\text { (jam) }\end{array}$ & $\begin{array}{l}312- \\
(6+19+12) \mathrm{x} \\
4.688 \\
=(312- \\
37) \times 4,688 \\
=275 \times 4,688 \\
=1.289,2 \\
=1.200 \\
\text { jam/thn } \\
=72.000 \\
\text { menit/thn }\end{array}$ & $\begin{array}{l}\text { Jam/ } \\
\text { Tahun }\end{array}$ \\
\hline
\end{tabular}

2. Tabel 3

Langkah 2 Menetapkan Waktu

Kerja Tersedia/WKT
3. Tabel 4

Langkah 3 Menetapkan Komponen Beban Kerja dan Norma Waktu

\begin{tabular}{lll}
\hline No. & Uraian Tugas & $\begin{array}{l}\text { Norma } \\
\text { Waktu }\end{array}$ \\
\hline 1. & Mendaftar pasien & 10 menit \\
2. & Membuatkan register & 8 menit \\
3. & $\begin{array}{l}\text { Label dan gelang } \\
\text { pasien rawat inap }\end{array}$ & detik \\
4. & Membuat tracer & 10 detik \\
& Total & $\mathbf{1 8 , 2 5}$ menit \\
\hline
\end{tabular}

4. Langkah 4 Menghitung Standar Beban Kerja (SBK)

Standar Beban Kerja $($ SBK $)=$ Waktu Kerja Tersedia

Norma Waktu/Kegiatan Pokok

Standar Beban Kerja $(\mathrm{SBK})=$

$$
\begin{aligned}
& \frac{72.000}{18,25} \\
= & 3.945
\end{aligned}
$$

5. Langkah 5 Menghitung Standar Tugas Penunjang (STP) dan Faktor Tugas Penunjang (FTP)

Faktor Tugas $=$ (Waktu Kegiatan $)$ :

Penunjang (WKT) $\mathrm{x} 100$

(FTP)

Standar Tugas $=(1 /(1-\mathrm{FTP} / 100))$

Penunjang(STP)

$\mathrm{FTP}=13,20: 72.000 \times 100 \%$

$$
=0,1 \%
$$

$\mathrm{STP}=(1 /(1-0,1 \% / 100))$

$$
=1
$$

6. Langkah 6 Menghitung Kebutuhan SDMK

\begin{tabular}{|ll|}
\hline \multirow{3}{*}{ Kebutuhan } & Capaian (1 th) \\
\cline { 2 - 3 } & XST \\
& Standar Beban
\end{tabular}

(Tim Pusrengun SDM Kesehatan Badan PPSDM Kesehatan RI, 2015)

\begin{tabular}{ll}
\hline Bagian & Capaian (1 th) \\
\hline Jumlah & 19.979 pasien/tahun \\
Pasien &
\end{tabular}

Kebutuhan Sumber Daya Manusia Kesehatan di bagian pendaftaran rawat inap dan IGD : 
$\mathrm{STP}=1$

SDMK $=19.978 / 3.945 x 1$

$=5$ orang petugas pendaftaran

C. Unit Assembling

1. Langkah 1 Menetapkan Fasyankes dan Jenis SDMK

Fasilitas Pelayanan Kesehatan :

Rumah Sakit

Unit : Assembling

2. Tabel 5

Langkah 2 Menetapkan Waktu Kerja Tersedia/WKT

\begin{tabular}{|c|c|c|c|}
\hline Kode & Komponen & Jumlah & Satuan \\
\hline $\bar{A}$ & Hari Kerja & $\begin{array}{l}52 \text { minggu } \times 6 \\
\text { hari }=312\end{array}$ & $\begin{array}{l}\text { Hari/ } \\
\text { Tahun }\end{array}$ \\
\hline B & $\begin{array}{l}\text { Cuti } \\
\text { Pegawai }\end{array}$ & 6 & $\begin{array}{l}\text { Hari/ } \\
\text { Tahun }\end{array}$ \\
\hline C & $\begin{array}{l}\text { Libur } \\
\text { Nasional }\end{array}$ & 19 & $\begin{array}{l}\text { Hari/ } \\
\text { Tahun }\end{array}$ \\
\hline D & $\begin{array}{l}\text { Mengikuti } \\
\text { Pelatihan }\end{array}$ & - & $\begin{array}{l}\text { Hari/ } \\
\text { Tahun }\end{array}$ \\
\hline $\mathbf{E}$ & $\begin{array}{l}\text { Absen } \\
\text { (Sakit,dll) }\end{array}$ & 12 & $\begin{array}{l}\text { Hari/ } \\
\text { Tahun }\end{array}$ \\
\hline $\mathbf{F}$ & $\begin{array}{l}\text { Waktu } \\
\text { Kerja } \\
\text { (dalam } \\
\text { minggu }\end{array}$ & 37,5 & $\begin{array}{l}\text { Jam/ } \\
\text { Minggu }\end{array}$ \\
\hline G & $\begin{array}{l}\text { Jam Kerja } \\
\text { Efektif } \\
(\mathrm{JKE})\end{array}$ & $\begin{array}{ll}75 \% & \mathrm{x} \\
37,5 \mathrm{jam} & = \\
28.125 & \end{array}$ & $\begin{array}{l}\text { Jam/ } \\
\text { Minggu }\end{array}$ \\
\hline H & $\begin{array}{l}\text { Waktu } \\
\text { Kerja } \\
\text { (dalam } \\
\text { hari) }\end{array}$ & $\begin{array}{l}28.125: 6= \\
4.688\end{array}$ & Jam/ Hari \\
\hline I & $\begin{array}{l}\text { Waktu } \\
\text { Kerja } \\
\text { Tersedia } \\
\text { (hari) }\end{array}$ & $\begin{array}{l}312- \\
(6+19+12)= \\
312-37=275\end{array}$ & $\begin{array}{l}\text { Hari/ } \\
\text { Tahun }\end{array}$ \\
\hline $\mathbf{J}$ & $\begin{array}{l}\text { Waktu } \\
\text { Kerja } \\
\text { Tersedia } \\
\text { (jam) }\end{array}$ & $\begin{array}{l}312- \\
(6+19+12) \times 4 . \\
688 \\
=(312- \\
37) \times 4,688 \\
=275 \times 4,688 \\
=1.289,2 \\
=1.200 \\
\text { jam/thn } \\
=72.000 \\
\text { menit/thn }\end{array}$ & $\begin{array}{l}\text { Jam/ } \\
\text { Tahun }\end{array}$ \\
\hline
\end{tabular}

3. Tabel 6

Langkah 3 Menetapkan Komponen

Beban Kerja dan Norma Waktu

\begin{tabular}{lll}
\hline No. & Uraian Tugas & $\begin{array}{l}\text { Norma } \\
\text { Waktu }\end{array}$ \\
\hline 1. & $\begin{array}{l}\text { Menggambil dokumen } \\
\text { rekam medis dipoli }\end{array}$ & menit \\
\hline 2. & $\begin{array}{l}\text { Memasukkan setoran } \\
\text { dokumen rekam medis }\end{array}$ & menit \\
tiap bagian ruang rawat \\
jalan,rawat inap \\
Menggurutkan dokumen \\
rekam medis menit \\
Total
\end{tabular}

5. Langkah 5 Menghitung Standar Tugas Penunjang (STP) dan Faktor Tugas Penunjang (FTP)

Faktor Tugas $=($ Waktu Kegiatan $)$ :

Penunjang (WKT) $\times 100$

(FTP)

Standar Tugas $=(1 /(1-\mathrm{FTP} / 100))$

Penunjang(STP)

$\mathrm{FTP}=13,20: 72.000 \times 100 \%$

$$
=0,1 \%
$$

$\mathrm{STP}=(1 /(1-0,1 \% / 100))$

$$
=1
$$

6. Langkah 6 Menghitung Kebutuhan

\begin{tabular}{|c|c|c|}
\hline \multirow{2}{*}{ Kebutuhan } & Capaian (1 th) & \multirow{2}{*}{ XSTP } \\
\hline & Standar Beban & \\
\hline
\end{tabular}
SDMK

(Tim Pusrengun SDM Kesehatan Badan PPSDM Kesehatan RI,

\begin{tabular}{|c|c|}
\hline Bagian & Capaian (1 th) \\
\hline $\begin{array}{l}\text { Jumlah } \\
\text { Pasien }\end{array}$ & 19.980 pasien/tahun \\
\hline
\end{tabular}
2015)

Kesehatan di bagian assembling :

SBK $=6.545$ 


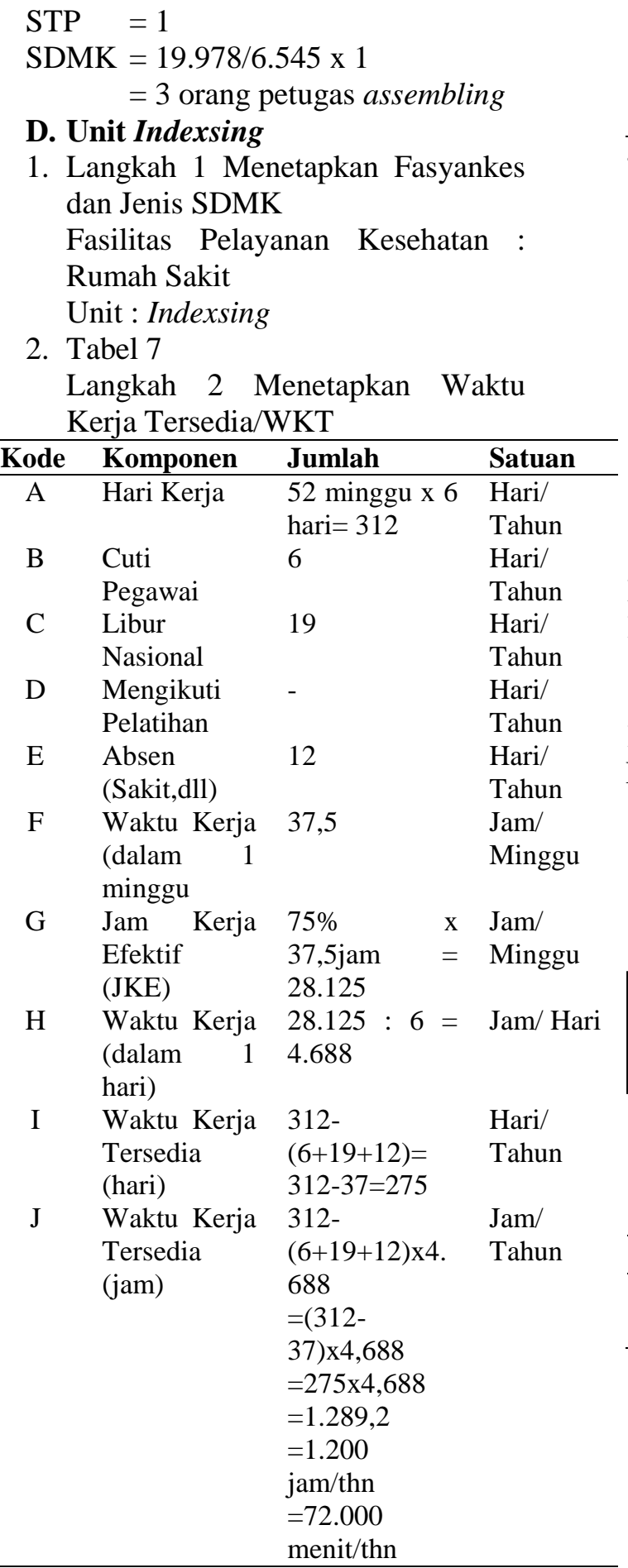

3. Tabel 8

Langkah 3 Menetapkan Komponen

Beban Kerja dan Norma Waktu

\begin{tabular}{llll}
\hline No. & Uraian Tugas & $\begin{array}{l}\text { Norma } \\
\text { Waktu }\end{array}$ \\
\hline 1. & $\begin{array}{l}\text { Input data unit rawat } \\
\text { jalan menit }\end{array}$ \\
2. & Input data unit rawat 2 menit
\end{tabular}

3. Input data unit gawat 2 menit darurat

Total

6 Menit

4. Langkah 4 Menghitung Standar Beban Kerja (SBK)

Standar Beban Kerja $(\mathrm{SBK})=$ Waktu Kerja Tersedia Norma Waktu/Kegiatan Pokok Standar Beban Kerja $(\mathrm{SBK})=$ 72.000

$$
=12.000
$$

5. Langkah 5 Menghitung Standar Tugas Penunjang (STP) dan Faktor Tugas Penunjang (FTP)

Faktor Tugas $=$ (Waktu Kegiatan): Penunjang (WKT) $x 100$

(FTP)

Standar Tugas $=(1 /(1-\mathrm{FTP} / 100))$

Penunjang(STP)

$\mathrm{FTP}=13,20: 72.000 \times 100 \%$

$=0,1 \%$

$\mathrm{STP}=(1 /(1-0,1 \% / 100))$

$$
=1
$$

6. Langkah 6 Menghitung Kebutuhan SDMK

\begin{tabular}{|lll}
\hline \multirow{2}{*}{ Kebutuhan } & Capaian (1 th) & \\
\cline { 2 - 2 } & Standar Beban & \\
\hline
\end{tabular}

(Tim Pusrengun SDM Kesehatan Badan PPSDM Kesehatan RI, 2015)

\begin{tabular}{ll}
\hline Bagian & Capaian $(1$ th $)$ \\
\hline Jumlah & 19.981 pasien/tahun \\
Pasien & \\
\hline
\end{tabular}

Kebutuhan Sumber Daya Manusia Kesehatan di bagian indexsing:

SBK $=12.000$

$\mathrm{STP}=1$

SDMK $=19.978 / 12.000 \times 1$ $=2$ orang petugas indexing 


\section{E. Unit Coding}

1. Langkah 1 Menetapkan Fasyankes dan Jenis SDMK

Fasilitas Pelayanan Kesehatan :

Rumah Sakit

Unit : Coding

2. Tabel 9

Langkah 2 Menetapkan Waktu

Kerja Tersedia/WKT

\begin{tabular}{|c|c|c|c|}
\hline Kode & Komponen & Jumlah & Satuan \\
\hline $\mathrm{A}$ & Hari Kerja & $\begin{array}{l}52 \text { minggu } \times 6 \\
\text { hari }=312\end{array}$ & $\begin{array}{l}\text { Hari/ } \\
\text { Tahun }\end{array}$ \\
\hline B & $\begin{array}{l}\text { Cuti } \\
\text { Pegawai }\end{array}$ & 6 & $\begin{array}{l}\text { Hari/ } \\
\text { Tahun }\end{array}$ \\
\hline $\mathrm{C}$ & $\begin{array}{l}\text { Libur } \\
\text { Nasional }\end{array}$ & 19 & $\begin{array}{l}\text { Hari/ } \\
\text { Tahun }\end{array}$ \\
\hline $\mathrm{D}$ & $\begin{array}{l}\text { Mengikuti } \\
\text { Pelatihan }\end{array}$ & - & $\begin{array}{l}\text { Hari/ } \\
\text { Tahun }\end{array}$ \\
\hline $\mathrm{E}$ & $\begin{array}{l}\text { Absen } \\
\text { (Sakit,dll) }\end{array}$ & 12 & $\begin{array}{l}\text { Hari/ } \\
\text { Tahun }\end{array}$ \\
\hline $\mathrm{F}$ & $\begin{array}{lr}\text { Waktu } & \text { Kerja } \\
\text { (dalam } & 1 \\
\text { minggu }\end{array}$ & 37,5 & $\begin{array}{l}\text { Jam/ } \\
\text { Minggu }\end{array}$ \\
\hline $\mathrm{G}$ & $\begin{array}{l}\text { Jam Kerja } \\
\text { Efektif } \\
(\mathrm{JKE})\end{array}$ & $\begin{array}{ll}75 \% & \mathrm{x} \\
37,5 \mathrm{jam} & = \\
28.125 & =\end{array}$ & $\begin{array}{l}\text { Jam/ } \\
\text { Minggu }\end{array}$ \\
\hline $\mathrm{H}$ & $\begin{array}{lr}\text { Waktu } & \text { Kerja } \\
\text { (dalam } & 1 \\
\text { hari) } & \end{array}$ & $\begin{array}{l}28.125: 6= \\
4.688\end{array}$ & Jam/ Hari \\
\hline I & $\begin{array}{l}\text { Waktu Kerja } \\
\text { Tersedia } \\
\text { (hari) }\end{array}$ & $\begin{array}{l}312- \\
(6+19+12)= \\
312-37=275\end{array}$ & $\begin{array}{l}\text { Hari/ } \\
\text { Tahun }\end{array}$ \\
\hline $\mathrm{J}$ & $\begin{array}{l}\text { Waktu Kerja } \\
\text { Tersedia } \\
\text { (jam) }\end{array}$ & $\begin{array}{l}312- \\
(6+19+12) \times 4 . \\
688 \\
=(312- \\
37) \times 4,688 \\
=275 \times 4,688 \\
=1.289,2 \\
=1.200 \\
\text { jam/thn } \\
=72.000 \\
\text { menit/thn }\end{array}$ & $\begin{array}{l}\text { Jam/ } \\
\text { Tahun }\end{array}$ \\
\hline
\end{tabular}

3. Tabel 10

Langkah 3 Menetapkan Komponen

Beban Kerja dan Norma Waktu

\begin{tabular}{lll}
\hline No. & Uraian Tugas & $\begin{array}{c}\text { Norma } \\
\text { Waktu }\end{array}$ \\
\hline 1. & Coding rawat jalan & 5 menit \\
2. & Coding rawat inap & 3 menit \\
3. & Coding gawat darurat & 2 menit \\
& Total & $\mathbf{1 0}$ Menit \\
\hline
\end{tabular}

4. Langkah 4 Menghitung Standar Beban Kerja (SBK)

Standar Beban Kerja $(\mathrm{SBK})=$ Waktu Kerja Tersedia Norma Waktu/Kegiatan Pokok Standar Beban Kerja $(\mathrm{SBK})=$

$$
\frac{72.000}{10}
$$$$
=7.200
$$

5. Langkah 5 Menghitung Standar Tugas Penunjang (STP) dan Faktor Tugas Penunjang (FTP)

Faktor Tugas $=$ (Waktu Kegiatan $)$ :

Penunjang (WKT) 100

(FTP)

Standar Tugas $\quad=(1 /(1-\mathrm{FTP} / 100))$

Penunjang(STP)

FTP $=13,20: 72.000 \times 100 \%$

$$
=0,1 \%
$$

$\mathrm{STP}=(1 /(1-0,1 \% / 100))$

$$
=1
$$

6. Langkah 6 Menghitung Kebutuhan SDMK

Kebutuhan $=\frac{\text { Capaian (1 th) }}{\text { Standar Beban }} \quad$ XSTP

(Tim Pusrengun SDM Kesehatan Badan PPSDM Kesehatan RI, 2015)

\begin{tabular}{ll}
\hline Bagian & Capaian $(1$ th $)$ \\
\hline Jumlah & 19.982 pasien/tahun \\
Pasien &
\end{tabular}

Kebutuhan Sumber Daya Manusia

Kesehatan di bagian coding:

SBK $=7.200$

STP $=1$

SDMK $=19.978 / 7.200 \times 1$

F. Unit Filling

1. Langkah 1 Menetapkan Fasyankes dan Jenis SDMK

Fasilitas Pelayanan Kesehatan :

Rumah Sakit

Unit : Filling 
2. Tabel 11

Langkah 2 Menetapkan Waktu

Kerja Tersedia/WKT

\begin{tabular}{|c|c|c|c|}
\hline Kode & Komponen & Jumlah & Satuan \\
\hline A & Hari Kerja & $\begin{array}{l}52 \text { minggu } x \\
6 \text { hari }=312\end{array}$ & $\begin{array}{l}\text { Hari/ } \\
\text { Tahun }\end{array}$ \\
\hline B & $\begin{array}{l}\text { Cuti } \\
\text { Pegawai }\end{array}$ & 6 & $\begin{array}{l}\text { Hari/ } \\
\text { Tahun }\end{array}$ \\
\hline $\mathrm{C}$ & $\begin{array}{l}\text { Libur } \\
\text { Nasional }\end{array}$ & 19 & $\begin{array}{l}\text { Hari/ } \\
\text { Tahun }\end{array}$ \\
\hline $\mathrm{D}$ & $\begin{array}{l}\text { Mengikuti } \\
\text { Pelatihan }\end{array}$ & - & $\begin{array}{l}\text { Hari/ } \\
\text { Tahun }\end{array}$ \\
\hline $\mathrm{E}$ & $\begin{array}{l}\text { Absen } \\
\text { (Sakit,dll) }\end{array}$ & 12 & $\begin{array}{l}\text { Hari/ } \\
\text { Tahun }\end{array}$ \\
\hline $\mathrm{F}$ & $\begin{array}{lr}\text { Waktu } & \text { Kerja } \\
\text { (dalam } & 1 \\
\text { minggu }\end{array}$ & 37,5 & $\begin{array}{l}\text { Jam/ } \\
\text { Minggu }\end{array}$ \\
\hline G & $\begin{array}{l}\text { Jam Kerja } \\
\text { Efektif } \\
(\mathrm{JKE})\end{array}$ & $\begin{array}{ll}75 \% & \mathrm{x} \\
37,5 \mathrm{jam} & = \\
28.125 & \end{array}$ & $\begin{array}{l}\text { Jam/ } \\
\text { Minggu }\end{array}$ \\
\hline $\mathrm{H}$ & $\begin{array}{lr}\text { Waktu } & \text { Kerja } \\
\text { (dalam } & 1 \\
\text { hari) } & \end{array}$ & $\begin{array}{l}28.125: 6= \\
4.688\end{array}$ & Jam/ Hari \\
\hline I & $\begin{array}{l}\text { Waktu Kerja } \\
\text { Tersedia } \\
\text { (hari) }\end{array}$ & $\begin{array}{l}312- \\
(6+19+12)= \\
312-37=275\end{array}$ & $\begin{array}{l}\text { Hari/ } \\
\text { Tahun }\end{array}$ \\
\hline $\mathrm{J}$ & $\begin{array}{l}\text { Waktu Kerja } \\
\text { Tersedia } \\
\text { (jam) }\end{array}$ & $\begin{array}{l}312- \\
(6+19+12) \mathrm{x} \\
4.688 \\
=(312- \\
37) \times 4,688 \\
=275 \times 4,688 \\
=1.289,2 \\
=1.200 \\
\text { jam/thn } \\
=72.000 \\
\text { menit/thn }\end{array}$ & $\begin{array}{l}\text { Jam/ } \\
\text { Tahun }\end{array}$ \\
\hline
\end{tabular}

3. Tabel 12

Langkah 3 Menetapkan Komponen

Beban Kerja dan Norma Waktu

\begin{tabular}{|c|c|c|}
\hline No. & Uraian Tugas & $\begin{array}{l}\text { Norma } \\
\text { Waktu }\end{array}$ \\
\hline 1. & $\begin{array}{l}\text { Menyiapkan dokumen } \\
\text { rekam medis rawat } \\
\text { jalan dan rawat inap }\end{array}$ & 3 menit \\
\hline 2. & $\begin{array}{l}\text { Mengembalikan } \\
\text { dokumen rekam medis }\end{array}$ & 3 menit \\
\hline \multirow[t]{2}{*}{3.} & $\begin{array}{l}\text { Mengantar berkas ke } \\
\text { poli }\end{array}$ & 3 menit \\
\hline & Total & $\begin{array}{ll}9 & \text { Menit }\end{array}$ \\
\hline
\end{tabular}

4. Langkah 4 Menghitung Standar Beban Kerja (SBK)

Standar Beban Kerja $(\mathrm{SBK})=$ Waktu Kerja Tersedia

Norma Waktu/Kegiatan Pokok

Standar Beban Kerja (SBK) =

$$
\frac{72.000}{9}
$$$$
=8.000
$$

5. Langkah 5 Menghitung Standar Tugas Penunjang (STP) dan Faktor Tugas Penunjang (FTP)

Faktor Tugas $=$ (Waktu Kegiatan $)$ : Penunjang (WKT) $x 100$

(FTP)

Standar Tugas $=(1 /(1-\mathrm{FTP} / 100))$

Penunjang(STP)

FTP $=13,20: 72.000 \times 100 \%$

$$
=0,1 \%
$$

$\mathrm{STP}=(1 /(1-0,1 \% / 100))$

$$
=1
$$

6. Tabel 1.25

Langkah 6 Menghitung Kebutuhan SDMK

\begin{tabular}{|lll|}
\hline \multirow{2}{*}{ Kebutuhan } & Capaian (1 th) & \\
\cline { 2 - 2 } & XSTP \\
& Standar Beban & \\
\hline
\end{tabular}

(Tim Pusrengun SDM Kesehatan Badan PPSDM Kesehatan RI, 2015)

\begin{tabular}{ll}
\hline Bagian & Capaian $(1$ th $)$ \\
\hline Jumlah & 19.983 pasien/tahun \\
Pasien & \\
\hline Kebutuhan & Sumber Daya Manusi
\end{tabular}

Kebutuhan Sumber Daya Manusia

Kesehatan di bagian Filling:

$$
\begin{aligned}
\text { SBK } & =8.000 \\
\text { STP } & =1 \\
\text { SDMK } & =19.978 / 8.000 \times 1 \\
& =3 \text { orang petugas Filling }
\end{aligned}
$$


PEMBAHASAN

Tabel 13

\begin{tabular}{|c|c|c|c|c|c|}
\hline No. & Unit & $\begin{array}{l}\text { Jumlah } \\
\text { SDMK } \\
\text { Saat ini } \\
\end{array}$ & $\begin{array}{l}\text { Jumlah SDMK } \\
\text { yang Seharusnya }\end{array}$ & $\begin{array}{l}\text { Kesenjangan } \\
\text { SDMK }\end{array}$ & Keadaan \\
\hline 1. & $\begin{array}{l}\text { Tempat Pendaftaran } \\
\text { Rawat Jalan,Rawat } \\
\text { Inap dan IGD }\end{array}$ & 8 & 9 & 1 & $\begin{array}{l}\text { Belum } \\
\text { Sesuai }\end{array}$ \\
\hline 2. & Assembling & 1 & 3 & 2 & $\begin{array}{l}\text { Belum } \\
\text { Sesuai }\end{array}$ \\
\hline 3 & Indexsing & 2 & 2 & 0 & Sudah Sesuai \\
\hline 4 & Coding & 1 & 3 & 2 & $\begin{array}{l}\text { Belum } \\
\text { Sesuai }\end{array}$ \\
\hline 5 & Filling & 3 & 3 & 0 & Sudah Sesuai \\
\hline $\begin{array}{l}\text { Ponor } \\
\text { di un } \\
\text { masin } \\
\text { perhit } \\
\text { ABK } \\
\text { Penda } \\
\text { dan I } \\
\text { Asser } \\
\text { petug } \\
\text { petug } \\
\text { petug } \\
\text { petug }\end{array}$ & $\begin{array}{l}\text { Rumah Sakit Umum “ } \\
\text { go memiliki beberap } \\
\text { t rekam medis yans } \\
\text { unit berdasarkc } \\
\text { gan dari peneliti deng } \\
\text { Kes meliputi } \\
\text { taran Rawat Jalan, R } \\
\text { iD berjumlah } 9 \text { oran } \\
\text { bling berjumlah } \\
\text { s, Indexsing berjumla } \\
\text { s, Coding berjumlah } \\
\text { s, Filling berjumlah }\end{array}$ & $\begin{array}{l}\text { Darmayu" } \\
\text { a petugas } \\
\text { an masing- } \\
\text { an hasil } \\
\text { an metode } \\
\text { Tempat } \\
\text { awat Inap } \\
\text { g petugas, } \\
3 \text { orang } \\
\text { h } 2 \text { orang } \\
3 \text { orang } \\
3 \text { orang }\end{array}$ & \multicolumn{3}{|c|}{$\begin{array}{l}\text { kesenjangan pemenuhan jumlah SDM } \\
\text { pada unit rekam medis yaitu bagian } \\
\text { pendaftaran, assembling, dan Coding } \\
\text { hal tersebut diketahui dengan cara } \\
\text { menghitung Metode Analisa Beban } \\
\text { Kerja Kesehatan (ABK Kes). } \\
\text { Penambahan sumber daya manusia di } \\
\text { bagian pendaftaran, assembling, dan } \\
\text { coding guna meningkatkan kualitas } \\
\text { kinerja di bagian tersebut hal ini } \\
\text { dikarenakan dalam kategori pendidikan } \\
\text { petugas tersebut bukan lulusan asli } \\
\text { rekam medis melainkan lulusan SLTA. }\end{array}$} \\
\hline
\end{tabular}

Metode ABK Kes adalah suatu metode perhitungan kebutuhan SDMK berdasarkan pada beban kerja yang dilaksankan oleh setiap jenis SDMK pada tiap fasilitas pelayanan pelayanan kesehatan (Fayankes) sesuai dengan tugas pokok dan fungsinya. Metode ini digunakan untuk menghitung kebutuhan semua jenis SDMK, ada 6 langkah Metode ABK Kes diantaranya, menetapkan Fayankes dan jenis SDMK, menetapkan waktu kerja tersedia (WKT), menetapkan komponen beban kerja dan norma waktu, menghitung standar beban kerja (SBK), mengkitung standar tugas penunjang (STP) dan faktor tugas penunjang (FTP), dan menghitung kebutuhan sumber daya manusia kesehatan (SDMK).

Berdasarkan data Rekapitulasi Kebutuhan Sumber Daya Manusia (SDM) di rekam medis diatas dengan Metode ABK-Kes terdapat

\section{KESIMPULAN}

Berdasarkan hasil penelitian yang telah dilakukan mengenai kebutuhan SDM di rekam medis berdasarkan metode analisis beban kerja kesehatan (ABK Kes) di Rumah Sakit Umum "Darmayu", peneliti dapat mengambil kesimpulan sebagai berikut :

1. Rumah Sakit Umum "Darmayu" Ponorogo adalah salah satu dari 6 Rumah Sakit yang ada di Kabupaten Ponorogo, yang memiliki beberapa unit rekam medis yang terbagi menjadi 5 yaitu unit Pendaftaran,__Assembling, Indeksing, Coding, Filling.

2. Berdasarkan hasil perhitungan kebutuhan sumber daya manusia dengan metode analisis beban kerja kesehatan (ABK-Kes) di RSU "Darmayu" Ponorogo menghasilkan kebutuhan tenaga rekam medis 1 
petugas bagian pendaftaran, 2 orang petugas assembling, dan 2 orang petugas coding.

\section{SARAN}

Saran peneliti dalam hasil penelitian sumber daya manusia di rekam medis berdasarkan metode ABK-Kes di RSU "Darmayu" Ponorogo adalah sebaiknya perlu penambahan sumber daya manusia yang asli lulusan rekam medis di bagian pendaftaran, assembling, dan coding untuk meningkatkan kualitas kinerja petugas di Rumah Sakit Umum "Darmayu" Ponorogo.

\section{DAFTAR PUSTAKA}

Hatta, Gemala R. 2008. Tujuan Rekam Medis. Jakarta: Universitas Indonesia.

Notoatmojo, Soekidjo, 2010. Metodologi Penelitian

Kesehatan. Jakarta: Rineka Cipta

Permenkes No: 269/MENKES/PER/III/2008 tentang Rekam Medis

Sugiyono. 2016. Metode Penelitian Kuantitatif, Kualitatif dan $R \& D$. Bandung: PT Alfabet.

Tim Pusrengun SDM Kesehatan Badan PPSDM Kesehatan RI, 2015. Buku Manual 01 Perencanaan Kebutuhan Sumber Daya Manusia Kesehatan Berdasarkan Analisis Beban Kerja Kesehatan. Jakarta

Undang-Undang RI No. 44 tahun 2009 tentang Rumah Sakit 